181

THE EFFECT OF HALOTHANE (H) ON THYROID AND HEPATIC FUNCTION IN THE PREGNANT EWE. A1len Erenberg, Frank Smith, Jr.). Univ. of Iowa College Med., Dept. Ped. and Anesth. Lowa City

To evaluate the effect of $\mathrm{H}$ and surgery on thyroid and hepatid function in the pregnant sheep, 14 date bred ewes from 104 to 134 days gestation were anesthetized with 0.5 to $1.5 \% \mathrm{H}$ in nitrous oxide and oxygen. The surgical procedure began 15 minutes later and 1 asted from 2 to $21 / 2$ hours. Serum samples were obtained prior to and at $1 / 2$ hour intervals for 2 hours after the start o $\mathrm{H}$ and at 24 and 48 hours post-operatively (PO). Pre-operatively the mean serum $( \pm \mathrm{SEM})$ thyroxine $\left(\mathrm{T}_{4}\right)$ and triiodothyronine $\left(\mathrm{T}_{3}\right)$ levels were $3.9 \pm 0.2 \mu \mathrm{g} / \mathrm{d} 1$ and $117 \pm 8.3 \mathrm{ng} / \mathrm{dl}$, respectively. The mean serum $\mathrm{T}_{4}$ level remained unchanged during the operative procedure but was elevated at 24 and 48 hours Po. The mean serum $\mathrm{T}_{3}$ leve 1 was lower at 2 hours post-anesthesia $(84.8 \pm 10.8 \mathrm{ng} / \mathrm{d} 1$, p 20.025 ) returning to the pre-operative level by 48 hours. The mean $\mathrm{T}_{3} / \mathrm{T}_{4}$ ratio was decreased at 2 and 24 hours post-anesthesia but returned to the pre-operative level by 48 hours. Pre-operatively, the mean SGOT ( \pm SEM) level was $8.5 \pm 2.9 \mathrm{IU} / \mathrm{L}$ and the SGPT $( \pm S E M)$ level was $61.7 \pm 7.1 \mathrm{IU} / \mathrm{L}$ and remained unchanged during the operative procedure. The mean SGOT level was increased at 48 hours PO $(21.4 \pm 3.8 \mathrm{IU} / \mathrm{L}, \mathrm{p}<0.025)$ and the mean SGPT level increased at 24 hours $(147.6 \pm 20.4 \mathrm{IU} / \mathrm{L}, \mathrm{p}<0.001)$ and 48 hours $(170.6$ $\pm 17.1 \mathrm{IU} / \mathrm{L}, \mathrm{p}<0.001)$ PO. Conclusion: In the pregnant ewe during the $3 \mathrm{rd}$ trimester, surgery under $\mathrm{H}$ anesthesia affects serum $\mathrm{T}_{4}$ and $T_{3}$ levels and $\mathrm{T}_{3} / \mathrm{T}_{4}$ ratio and hepatic function tests for 48

182

PLACENTAL IMPERMEABILITY TO PARATHORMONE (PTH) I-125 IN THE EWE. Allen Erenberg, Mary $M$. Weinstein, I-Wen Chen and Reginald C. Tsang. U. of Iowa Coll. of Med., Dept. Ped., Iowa City and U. of Cincinnat 1 Coll. of Med., Dept. Ped. , Cincinnati, Oh.

Studies altering plasma calcium levels have demonstrated that the maternal (M) and fetal (F) parathyroid glands appear to func tion automonously and suggest a lack of placental permeability to PTH. To determine whether the ovine placenta is permeable to PTH I-125, catheters were placed into the F abdominal aorta and pedal vein and $M$ abdominal aorta and jugular vein in 5 date bred ewes at 121 to 135 days gestation. The studies were conducted 24 to 48 hours after surgery when the $M$ and $F$ arterial blood gases and $\mathrm{pH}$ returned to normal. Purified intact bovine PTH (184) was iodinated by the chloramine-T method. The placenta transfer of tracer quantities of PTH I-125 was studied in 5 animals in the $M \rightarrow F$ and 4 in the $F \rightarrow M$ direction. Simultaneous serial $\mathrm{F}$ and $\mathrm{M}$ plasma samples were obtained during the 60 minute study period and precipitated with $15 \%$ trichloracetic acid and the results expressed as percent dose/liter plasma. During the initial 20 minutes of the study, the $t 1 / 2$ was 21 minutes ( $r=$ $-0.99)$ in the $F$ and 21 minutes in the $M(r=-0.99)$. In the $M \rightarrow F$ studies, no more than $0.3 \%$ of the injection dose/liter plasma was detected in the $F$ and in the $F \rightarrow M$ studies, no more than $0.5 \%$ of the injected dose/liter plasma was detected in the $M$ at 15 to 30 minutes post injection. Thus, during the 3 rd trimester, the ovine placenta is impermeable to PTH I-125. The $t 1 / 2$ of PTH I125 is similar in both the ovine $F$ and $M$.

\section{Rostaglandin SYNTHETASE IN THE HUMAN NEONATAL KIDNEY} vi Friedman, Laurence Demers. (Spon. by Nicholas M.
Penn State Univ Coll Med, M. S. Hershey Med Ctr, Dept Ped, Hershey, PA.

Prostaglandin (PG) biosynthesis by the mammalian kidney occurs mainly in the medulla (II) and PG breakdown takes place mainly in the cortex (C). We have studied the PG synthetase system in 6 the cor tew idneys $(16,22,26,28,31,32$ weeks of gestation) 2 hours after death. Slices of $M$ and $C$ were incubated in a medium containing $50 \mathrm{~kg}$ arachidonic acid (AA) and $50 \mu \mathrm{Ci}\left[{ }^{3} \mathrm{H}\right]-\mathrm{AA}$. The incorporation of $\left[{ }^{3} \mathrm{H}\right]-\mathrm{AA}$ into PGE, PGF and PGA was determined at 30 -min. intervals in $M$ and $C$ tissue and in the incubation medium over 3 hrs. using silicic acid chromatography and scintillation counting. [ $\left.{ }^{3} \mathrm{H}\right]-\mathrm{PG}^{\prime} \mathrm{s}$ were not detected in $\mathrm{C}$ tissue but PGA was dereted in $C$ medium in infants $\leq 26$ weeks of gestation. After $1 \mathrm{hr}$, PGs (mean values) in the $M$ medium were ( $\mathrm{cpm} / \mathrm{mg}$ tissue):

$\begin{array}{llc} & \leq 26 \text { weeks } & \geq 28 \text { weeks } \\ \text { PGE } & \text { not detected } & 210 \\ \text { PGF } & \text { not detected } & 220 \\ \text { PGA } & 5000 & 85\end{array}$

The renal concentration of the essential fatty acids which are PQ precursors varied only slightly with advanced gestation. Detection of different $P G$ compounds may relate to changes occurring in the PG synthetase system complex, in PG metabolism or both durin maturation. The study demonstrates that the renal medulla and cortex are associated with $P G$ synthesis in infants $\leq 26$ weeks of gestation and that the renal medulla is the main site for PG syn-
thesis in the maturing kidney $\geq 28$ weeks of gestation.

184

INSULIN DEGRADATION WITHIN THE FETO-PLACENTAL UNIT, Robert E. Greenberg and Belina Avner, Dept. of Ped.,

The concentration of insulin in fetal plasma is a resultant of factors stimulating insulin secretion and/or metabolic disposition. As part of investigations of the dynamics of fetal insulin secretion, aspects of insulin disposition in placenta and fetus were studied. Inactivation of insulin could occur by cleavage of disulfide bonds with glutathione-insulin transhydrogenase (GIT), and/or by proteolysis with specific or nonspeciflc peptidases.

Activity of GIT is negligible in fetal liver until day 18 of gestation, when the specific activity is 21 units/mg. protein, as compared to 127 units/mg. protein at term. Activity of GIT in fetal kidney and lung, during late gestation, is comparable to adult values. Non-GIT activity was excluded by 1ncubation with N-ethyl maleimide. Placental GIT activity was constant throughout gestation. Identification of GIT as initial step in degradation of insulin by placental homogenates, microsomes and membrane preparations was established by Sephadex chromatography membrane preparations was established by Sephadex chromatograp cellular distribution of GIT differs between placenta and liver, with much less activity in placental microsomes.

These studies indicate that fetal liver cannot degrade insulin until late in pregnancy. It is probable that the placenta plays a significant role in disposition of insulin and, thus, in regulation of the plasma concentration of insulin in the rat fetus.

185 COMPARISON OF UMBILICAL GLUCOSE UPTAKE AND FETAL GLU185 Barbara J. Quissell, Frederick C. Battaglia, Giacomo Meschia. University of Colorado Medical Center, Department of Pediatrics, Denver.

Net fetal glucose uptake has been measured by us previously in fetal lambs using the Fick Principle. This study compares simultaneous measurements of net fetal glucose uptake with fetal glucose turnover rates, using primed-constant infusions of ${ }^{14} \mathrm{C}$ $\mathrm{I}$-glucose and either ${ }^{3} \mathrm{H}-2$ or $3 \mathrm{H}-6$-glucose carried out in chronic animal preparations. The glucose turnover rates of placenta plus fetus, expressed as $\mathrm{mg} \mathrm{min}^{-1} \mathrm{Kg}^{-1}$ were: $12.02 \pm 1.35 \mathrm{SEM}\left({ }^{14} \mathrm{C}\right.$ label) and 13.78+1.61 SEM ( $3 \mathrm{H}$ label). However, the placenta accounted for a large fraction of these turnover rates. Forty to seventy percent of the infused labeled glucose was taken up by the placenta. The glucose turnover rates of the fetal body (mg min $\mathrm{Kg}^{-1}$ ) were: $5.22 \pm 0.62 \mathrm{SEM}\left({ }^{4} \mathrm{C}\right.$ label) and $8.85 \pm 1.63 \mathrm{SEM}\left({ }^{3} \mathrm{H}\right.$ labe1). The simultaneously measured fetal glucose uptake via the umbilical circulation was $4.81 \pm 0.37 \mathrm{SEM}$ ( $\mathrm{mg} \mathrm{min}-1 \mathrm{Kg}^{-1}$ ). In 4 of 6 animals, fetal glucose uptake and the turnover rate of ${ }^{14} \mathrm{C}-1-\mathrm{glucose}$ by the fetal body were virtually equal. Of the inand $\sim 7 \%$ to lactate by the placenta. Previous studies of fetal glucose turnover have not discriminated between placental uptake and turnover rate within the fetus. This study demonstrates such discrimination is feasible and should lead to a more meaningful comparison between fetal and neonatal metabolism.

186 DEVELOPMENTAL CHARACTERISTICS OF HUMAN F-CELLS. Verle E. Headings, Stephen I.O. Anyalbe, and Syama P. Bhattacharya. Howard University College of Medicine, Division of Medical Genetics, Department of Pediatrics and Child Health, and Center for Sickle Cell Disease. Washington, D.C.

The total quantity of fetal hemoglobin (Hb F) 1s subfect to developmental, humoral, pathological and genet1c varlables. The developmental and humoral mechanisms which effect changes In Hb F might be further clarified by comparing the dynamics of F-cell number and quantities of $\mathrm{Hb} F / F-c e l l$. Changes in relative numbers of $\mathrm{F}-\mathrm{cell}$ s and $\mathrm{A}-\mathrm{cel} 1 \mathrm{~s}$ and quantities of $\mathrm{Hb} \mathrm{F} / \mathrm{F}-$ cell and $\mathrm{Hb} \mathrm{A} / \mathrm{A}-\mathrm{cell}$ were measured by single cell 1mmunodiffusion, using fluorescein-confugated anti-Hb $\mathrm{F}$ and anti-Hb $\mathrm{A}$, in term cord blood, 3-month old chlldren, and nonpregnant and pregnant adults. Over the indicated developmental interval relative $\mathrm{A}-c e l 1$ number and mean $\mathrm{Hb} \mathrm{A} / \mathrm{A}$-cell 1 ncreased 1.71 and 1.40, respectively. In contrast relative $F-c e l l$ number and mean $\mathrm{Hb} F / F-c e l l$ declined 26.23 and 1.32 fold, respectively. In the female at midtrimester pregnancy A-cell number and Hb A/A-cell increased 1.07 (NS) and 1.01 (NS) fold, respectively, whereas these same parameters for F-cells increased 2.96 and $1.14 \mathrm{fold}$. It 18 concluded that within the detection range of the 1manunodffusion technique both the mean intracellular quantity of $\mathrm{Hb} F$ and the $F$-cell frequency show decrease during late development, but at dissimilar rates. Presumably humoral signals in midtrimester pregnancy promote disproportionate increases in both F-cell frequency and detectable $\mathrm{Hb}$ F/F-cell. 